\title{
Elite perceptions of change in English local government: comparisons between Conservative and New Labour Governments
}

Commonwealth Journal of Local Governance

Issue 13/14: November 2013

http://epress.lib.uts.edu.au/ojs/index.php/cjlg

\author{
Andy Asquith \\ Senior lecturer \\ Massey University, School of Management \\ New Zealand \\ Email: a.asquith@massey.ac.uk
}

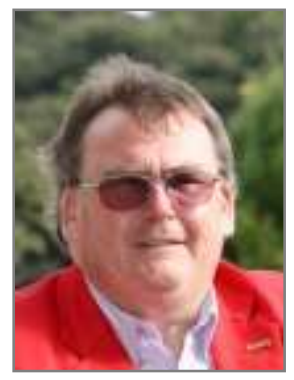

\begin{abstract}
In 1997 Local Government Studies published an article (Asquith, 1997) which assessed the perceptions of managerial and political elites in eight English local authorities towards change management against the background of Conservative Governments' reform agendas. The article argued that the authorities could be placed on a continuum depending on their state of organisational evolution, with some authorities being better equipped to manage change than others. During 2005 the authorities were revisited to ascertain how they had adapted to deal with the reforming Blair Governments since 1997. What this article shows is that characteristics evidenced in the original work in the authority deemed to have evolved the most, were present in those authorities revisited.
\end{abstract}

\section{Introduction}

This paper revisits work undertaken in the 1990s which examined the role of eight English local authority chief executives in implementing and managing change, within the constraints imposed by internal managerial and organisational politics and the broader political environment. Extensive interviews were conducted with managerial and political elites to ascertain the nature of change management in the early 1990s. The findings were reported in Local Government Studies (Asquith, 1997), along with the results of an extensive employee attitudes survey in the eight authorities conducted at the same time (Asquith, 1998). Further, the article adds to the growing body of knowledge relating to the changing role of local authority chief executives (c.f. Dahler-Larsen, 2002; Morphett, 1990; Morphett, 1993; Morris and Paine, 1995; Mouritzen and Svara, 2002; Norton, 1991; Skelcher, 2010a; Skelcher, 2010b). 
Given that the reforming Labour Governments of Tony Blair had a keen interest in the activities of local government, not least to ensure key policies on primary and secondary education - which are the responsibility of local government - are delivered, it seemed timely in 2005 to revisit the authorities in the original research to ascertain the state of play after eight years of new Labour reform. Access was therefore sought to the chief executive within the original sample organisations. Six out of the sample agreed to facilitate a meeting. The local authorities can be characterised thus:

- A radical reforming London borough (L1) very much at the forefront of New Labour thinking. One of the first to adopt the 'Directly Elected Mayor' model. The move to the Mayoral model was seen as a continuation of the innovative approach to organisation, management and service delivery evident during the original fieldwork in 1991. The chief executive here had been a chief officer within the authority at the time of the original research and was the second-longest serving chief executive in London. Hence the authority had experienced managerial continuity.

- A London borough (L2) seen by many as the 'model' advocated by successive Conservative ministers. At the time of the original research it had been engulfed in both managerial and political leadership crises. Despite a change of Government, the authority still saw itself as being at the cutting edge of developments in local government and had recently been awarded the title of 'Council of the Year' by its peers. Access in 2005 was provided to the Director of Policy who had held a less senior role in the organisation in the early 1990s.

- A northern metropolitan authority (M1) which in the intervening period between the time of the original work and 2005 had undergone a number of internal organisational crises. The chief executive in 2005 had held a chief officer post in the organisation during the original research.

- A shire county (S1) in the midlands which in the early 1990s had to deal with the resignation of a reforming chief executive in disgrace and the imprisonment of a reforming Leader of the Council. In the intervening period the authority had lost a significant area of land and population during local government reorganisation. The chief executive in 2005 had served as a chief officer with the authority prior to her appointment, and before that had been a chief officer in the northern metropolitan authority (M1).

- A small shire district (D1) within the county (S1) (above). This chief executive had remained in post throughout the time period. At the time of the original research this authority was unusual in that all of its councillors were elected as 'Independents' and it contained no party 'Political' members.

- A south coast city (D2) which at the time of the original work had had a chief executive who was unsuccessfully attempting a major change programme. The intervening period had seen a new chief executive who had dealt with the authority gaining unitary status by simply 'bolting' on the newly acquired functions. In 2004 the authority had appointed a chief executive with a 
distinct remit to radically transform the organisation in order to equip it with the organisational capabilities required to meet the challenges posed by the Blairite reform agenda. Less than a year later, this chief executive departed the authority after the refusal of elected members to accept and endorse the radical change agenda advocated.

In addition to these six organisations, the two others where access was sought but denied were:

- A northern metropolitan borough (M2) which following the change in political administration in 2004 had parted company with the chief executive. The interim/acting chief executive felt unable to participate in the research.

- A midlands shire county (S2) where the chief executive who had been in post since the time of the original research was approaching retirement, and declined to participate in the research.

The original research placed the eight authorities in a typology which categorised the organisations according to a number of common characteristics. The placement of each local authority was the result of circa 100 interviews with chief executives, chief officers and leading elected members in all eight authorities. The authorities were placed in the typology as they exhibited mostly features of that type:

- Transactional - Introverted bureaucratic organisations which lacked chief executive leadership, with power revolving around traditional chief officer/committee chair/councillor relationships.

- $\quad$ Community Leadership - Unified managerial/political focus on community, yet hindered by insular corporate management style.

- Business Culture - Low appreciation of community, highly commercialised/managerial focus driven solely by the provision of statutory obligations.

- Entrepreneurial Citizenship - Combination of the managerial/political focus on community with a strong emphasis on commercial efficiency and effectiveness (see Table 1).

Table 1: Typology of authorities interviewed

\begin{tabular}{|l|l|l|l|l|}
\hline Authority type & Transactional & $\begin{array}{l}\text { Community } \\
\text { Leadership }\end{array}$ & $\begin{array}{l}\text { Business } \\
\text { Culture }\end{array}$ & Entrepreneurial Citizenship \\
\hline $\begin{array}{l}\text { Managerial \& } \\
\text { political focus }\end{array}$ & $\begin{array}{l}\text { Internal - } \\
\text { rule bound }\end{array}$ & $\begin{array}{l}\text { External - } \\
\text { effectiveness }\end{array}$ & $\begin{array}{l}\text { Internal - } \\
\text { efficiency }\end{array}$ & $\begin{array}{l}\text { External - effectiveness } \\
\text { Internal - efficiency }\end{array}$ \\
\hline $\begin{array}{l}\text { Managerial } \\
\text { philosophy }\end{array}$ & $\begin{array}{l}\text { Bureaucratic/ } \\
\text { Weberian }\end{array}$ & Corporate & $\begin{array}{l}\text { Strategic } \\
\text { (Commercial) }\end{array}$ & $\begin{array}{l}\text { Strategic } \\
\text { (Governance) }\end{array}$ \\
\hline $\begin{array}{l}\text { Perception of } \\
\text { service users }\end{array}$ & Recipients & Citizens & Customers & Citizens \\
\hline $\begin{array}{l}\text { Strategic actor } \\
\text { support }\end{array}$ & No & Yes & Yes & Yes \\
\hline $\begin{array}{l}\text { Street level } \\
\text { support }\end{array}$ & No & No & Yes & Yes \\
\hline Authorities & D2; S1 & D1; M1 & L2; M2; S2 & L1 \\
\hline
\end{tabular}

Source: Adapted from Asquith (1997) and (1998) 
It was previously argued (Asquith 1997) that the types represented a continuum, with each of the stages being evolutions on the preceding stage, moving left to right. Hence, the Entrepreneurial Citizenship classification, it was argued, was the most advanced organisational type, with one authority, L1, actively seeking to demonstrate those characteristics - having previously been classified as being a Community Leadership authority.

There appears to be striking similarity in the characteristics between the Entrepreneurial Citizenship authorities and the model local authority espoused in the raft of legislation concerning local government passed by the Blair administration, a model described as Enlightened Public Governance (Thynne, 2003) or New Public Governance (Osbourne, 2006; 2010). Hence, common themes existed around issues of: internal efficiency; external effectiveness and community engagement. These themes exhibited themselves in two primary policy thrusts post 1997, namely: democratic renewal and the shift from local government to local governance. The latter is the realisation that a local authority has a legitimate right to lead its community, yet cannot alone achieve all the objectives it aspires to - it must act in partnership with other public sector bodies, the private sector and the not-for-profit sector.

\section{New Labour: new local government?}

The most striking thing about the interviews conducted in 2005 was the general, if somewhat reluctant, agreement about the way in which local government was viewed by central government. Whilst no one signed up to the New Labour agenda without some kind of reservation, there was at least a grudging respect for what the post 1997 reforms had offered local government. This can be contrasted to the so-called 'dark' days of the 1980's and early 1990s when Davis (1988) argued that local government was 'under siege'. Indeed, analysis of the interview transcripts from the early 1990s shows the dominance within local government of two key issues. These were: the Community Charge or Poll Tax - a single charged imposed upon all adults within a local authorities area, and Compulsory Competitive Tendering - the compulsory use of market forces in the provision of some local government functions.. One of the 2005 interviewees commented that the combination of the Poll Tax and Compulsory Competitive Tendering had in effect placed local government managers in the role of service reducers. As one chief executive observed:

Well I have to say for both in my perspective here, in general it has been very positive because the amount of money that is coming to public service and the environment that I have worked in as a senior manager has been one way you have been able to develop service since 1997, whereas up to 1997 all we did was reduce service

In contrast, the situation in 2005 meant that they were able to think and plan strategically to develop and deliver services for the community. Despite this however, fears still exist as to the extent to which local government was being 'neutered' and 'nationalised' through the continued retention and use of instruments such as Council Tax capping - whereby the maximum level of taxation raised by a local authority is set centrally by national government - thereby fundamentally undermining a key principle 
of local democracy. Indeed one chief executive suggested that if the centralisation trend continued he would cease to be an employee of the local authority and be on the payroll of Her Majesty's Government, observing on the cumulative effect of the New Labour reforms thus:

I think services to the public are better, local government is weaker... the role of the managerial leader in local government has been elevated... Local political enterprise is being devalued and managerial enterprise has been revalued. Government has increasingly declined to talk to local political leaders but will talk to local managerial leaders.

Interesting, this theme is further articulated by Skelcher when he comments that after 12 years of Labour Administrations has resulted in:

Its overall impact on officer-member relationships has been to strengthen the role of the former, at the expense of the latter... (2010b: 336)

It was clear from the 2005 interviewees that there existed a view that central government did not quite grasp the diversity inherent within local government, and the stark differences which exist between city or urban local government and managing in a rural local authority. There was a clear undercurrent which suggested that the post 1997 reform agenda - in particular towards local authority internal management arrangements (see below) - had been dominated by organisations such as the New Local Government Network, a Blairite local government think tank, whose leading actors come from principally urban local authorities. Hence, it was suggested that central government was to some extent pursuing a 'one size fits all', standardising agenda which was clearly inappropriate to many rural local authorities.

The one policy which was specifically identified for criticism here was the Democratically Elected Mayor model of internal organisation, the pursuit of which, it was argued, was the result of the then Prime Minister's interest in American models of management. Whilst this mode of organisation may be deemed to be appropriate for urban authorities, it was argued that in thinly populated rural authorities there was little interest in the 'Directly Elected Mayor' model. As the chief executive of S1 wryly commented:

Blair has, his obsession with choice and privatisation and American way of doing things are very very urban models which just do not fit into a rural environment...

There is no way you will ever get people of S1 shire saying 'we want an elected Mayor because people who live in Town A have one. They wouldn't have a bloody clue who the elected Mayor from Town A was, because it is nearly 80 miles away in the car. I do think the Labour Government has been incredibly urban centric.

Elsewhere within the urban authorities, L2 and M1, support for the 'Directly Elected Mayor' was not strong. The perceived concentration of power in one individual was seen as being detrimental to the nature of local democracy whereby a council took decisions as a whole. It is the view of the writer however, that the managerial and political instability which was evidenced in both L2 and M1 during the period 1990-2005 - in contrast to the marked stability in L1 - has resulted in organisations lacking both the maturity and confidence needed to successfully operationalise the 'Directly Elected Mayor' model to the maximum benefit of the locality. 
An interesting aside to the whole New Labour agenda arose around the views expressed towards the idea of individual choice being advanced by Le Grand (2002) amongst others. Indeed those interviewed were very vocal on this issue, taking the government to task over the language chosen to describe the individual - citizen, service user, consumer or customer, as being generally irrelevant. The general consensus was that the title did not matter - least of all to service recipients, just as long as they benefited from timely, effective services which were appropriate to their individual needs. What did cause considerable consternation was the pursuit of choice by central government. It was consistently argued that as long as service recipients benefited from the timely effective services noted above, then choice was an irrelevancy. Further, it was argued that in an urban area, where service providers may be numerous, such as schools, within a large rural county where schools may be over 20 miles apart, the idea of choice was a misnomer. This debate was summarised effectively by one interviewee thus:

I don't get too carried away with citizen or customer or resident or whatever. The principle is that you treat them as king and how you respond with the service, rather than you have this structure and service in place and it is up to you guys to find the best way in.

The general tone of New Labour's approach to local government was set out in a raft of consultation documents published in 1998 by the then Department of the Environment, Transport and the Regions and which evolved into the White Paper, Modern Local Government In Touch with the People (DETR, 1998), which in turn became the Local Government Act 2000. These consultation documents dealt with a range of issues affecting local government. A review of the literature generated by the Blair agenda vis a vis local government demonstrates a three-pronged approach based around the internal management arrangements of local authorities; enhancing performance management regimes and the wider issue of local governance not government (Hartley et al, 2002; Newman et al, 2001, Painter et al 2003; Wilson, 2005; Wilson and Doig, 2000).

There was a general agreement amongst those interviewed in 2005 that the New Labour agenda had had a generally positive impact upon local government in England. What is interesting is that both London Boroughs felt that they had been instrumental in setting this agenda in terms of governance and efficiency - despite consistently representing very different party political positions.

\section{Internal organisational dynamics}

By far the most important changes here relate to the reforms introduced by the Local Government Act 2000 (Rao, 2003). These reforms offered all local authorities over the size of 85,000 in population the choice of one of three systems of political organisation:

- Leader with a Cabinet - whereby the leader of the largest political grouping on a council would form a cabinet of portfolio holders. This model was seen as the one involving the least change, and was adopted by over $90 \%$ of all local authorities. 
- Directly Elected Mayor with a Cabinet - whereby a popularly elected mayor would select a cabinet from elected councillors. This was the model advocated by Blair Government. However it was only adopted by 13 local authorities in total, being later abandoned in two of these.

- Directly Elected Mayor with a Manager - the most radical model, envisaging the role mayor as akin to that of a private sector style chairperson, with the city manager fulfilling the chief executive role. This option was abolished in 2007.

Within the eight sample authorities, seven had chosen the Leader with a Cabinet option - in line with over 97\% of all local authorities. One of the London Boroughs (L1) had however sought the more radical option of the Mayor with a Cabinet. In fact, before the legislation was in place, the Council had delegated authority to an Executive Committee led by an appointed Mayor with executive power (Asquith, 2008).

Of those authorities that had adopted the Leader with a Cabinet model, the differing rationales offered stark contrasts. In L2 which had been characterised by one of its' chief officers as being more like a 'Hanson than a Marks and Spencer' (Asquith, 1997), in that it had no all-embracing corporate culture, such as Marks and Spencer, rather it functioned as a number of loosely associated departmental cultures, similar to that in a holding company such as Hanson plc., with each department driven by dominant committee chair/chief officer relationship. However in 2005, it was argued that such relationships operated successfully within the 'Leader with a Cabinet' model, which had been enthusiastically embraced as a mechanism to ensure that strategic governance was maintained, with the reforms providing a 'corporate glue', and that the collective nature of Cabinet government would serve to prevent aberrant leadership episodes such as that affecting L2 during the 1980s and 1990s.

Here, it is interesting to note that the chief executive of L1 argued that the 'Leader with a Cabinet' model had the potential to create Cabinet fiefdoms similar to those evidenced during times of crises within L2 - and as such presented the potential to legitimise the departmentalism exhibited previously in L2 and elsewhere. Indeed, such dangers were also voiced in D2, where the chief executive had purposefully created a management structure which did not mirror roles and responsibilities of Cabinet portfolio holders, attempting to prevent the re-creation of fiefdoms previously evident in the authority.

A major criticism of the reform agenda was the fact that all the models offered differing degrees of power concentration at the expense of the wider group of elected members. In one of the London Boroughs this was specifically flagged up as being an issue. Certainly in the past the authority had been used as a stepping stone to either national politics or prominence in local government circles. However, the feeling was that given the restriction of five to seven high profile positions within the organisation as Cabinet Members, this might restrict the flow of people of the right calibre seeking election to local government. What was not addressed, however, was the opportunity in the past for small number individuals to create semi-autonomous power baronies as the chair of a powerful 
Council committee - something which had been prevalent in this particular authority. Away from London, it was interesting to note that interviewees reported both a drop in the average age of elected members and an increase in the calibre of elected councillors. As such it was argued that the quality of debate and ultimately the decision-making process had benefited from the post-2000 reforms.

Elsewhere, in M1, prior to the Local Government Act 2000, the authority recorded over 80 internal decision making bodies, which ultimately led to corporate chaos. The restructuring of the decisionmaking machinery to fit the 'Leader with a Cabinet' model provided the authority with political and managerial coherence and strategic direction. Elsewhere, it was argued that the concept of Cabinet responsibility had served to undermine previously strong committee chair/chief officer relationships which had effectively derailed attempts to manage the authority strategically.

The issue of power concentration noted above was not felt to be a cause of concern in L1 where the 'Directly Elected Mayor with a Cabinet' model had been adopted. It was argued that such a model had had a positive impact upon local democratic accountability. The operationalisation of the model in L1 resulted in there being a single, easily identifiable person directly accountable to the populace. However, any power that person had was constrained by both the Cabinet and, of key importance, by internal organisational and party political conventions. Certainly it was argued that given the role the Directly Elected Mayor has pursued, the net impact has been a marked upturn in both interest and involvement in local democracy in the borough, with for the first time, citizens knowing exactly where the buck stops - with one identifiable individual rather than a bureaucratic machine:

I would say also that in the last few years, they take more people back to the councils because they know he is making the decision, they know he is the mayor and so the rule form is that the mayor makes the decision in the presence of officers who are advising him on professional grounds and his cabinet who are advising him about the politics of the issue which is very different from virtually every other councils, where the decision is made in the committee or in some circumstances is delegated to any one person, the mayor or chief officer, so we are very very corporate...(we are) probably more corporate than perhaps some of the mayoral councils would be like us .... we are more corporate than anyone you'd find.

The local election results of 2006 which saw the first re-election campaign in L1 of the Democratically Elected Mayor witnessed both an increased level of voter participation and an increased level of support for the incumbent. Interestingly, this pattern was also evident in all the Mayoral re-election contests held during May 2006. This pattern was again largely replicated in the subsequent round of Mayoral elections in 2010. The desire to see the 'Democratically Elected Mayoral' model work has led to further innovations in L1 which were designed to increase levels of participation in the democratic process amongst the population, away from traditional participatory activities of simply casting a vote every four years. The widespread use of Citizens' Juries and the innovative introduction of a Young Persons Mayor have served to encourage additional inputs into the workings of the local authority from groups often seen as being socially excluded from the mainstream (Quirk, 2006). 
The authority (L1) concerned has a history (of over 20 years) of stable political and managerial leadership with clearly understood political/managerial boundaries. In the early 1990s a number of senior officers (including the then chief executive and the assistant chief executive) had previously served elsewhere as elected members. During the fieldwork in 2005, it was suggested by the writer that this had been a significant factor in the political/managerial harmony within the organisation, in that senior managerial personnel were familiar with the pressures which characterise the world of the elected councillor. However, in 2005 the chief executive was adamant that this so-called 'twintracking' had not been the primary cause of the political/managerial harmony - it may have helped, but was by no means the driver. However, it remains the view of the writer that given the internal managerial/political environment within L1, when compared to the other seven authorities in the sample, that this represented a positive example of the potential benefits twin tracking offered towards the strengthening of managerial and democratic understanding within local government. Given the experiences in L1, it may be timely to revisit or revise the Local Government and Housing Act (1989) which outlawed twin-tracking.

The perceived success of the 'Directly Elected Mayor' model within L1 may also be attributed to other unique local factors. The Directly Elected Mayor had been one of two very high profile councillors who had dominated local politics since the mid-1980s. Indeed his profile was significantly enhanced locally by the television programme 'Town Hall' which chronicled the machinations within the authority for a 12 month period when he was Leader, and by a period when he ceased being a councillor, but undertook another high profile activity as chairman of the local hospital board. Hence, whilst not on the local authority, he held an equally high profile role in the local community. Such a high profile, the chief executive argued, aided the role he now undertakes as Directly Elected Mayor.

The Mayoral election results of May 2006 added a new dimension to the equation. Whilst the Mayor secured re-election with an increased turnout and an increase in the number of votes received, the political party he represents lost control of the Council for the first time in over twenty years. Interestingly, the Mayor was re-elected again in 2010 with an increased vote and the political party he represents also regained control of the authority. One can speculate that the political party was a benefactor of the Mayor's profile.

This 'public presence' was demonstrated, in a poll conducted by the borough in 2005, which showed that the Directly Elected Mayor enjoyed a higher recognition rating than any of the Members of Parliament who represent the borough $-31 \%$ compared to $29 \%$. The chief executive attempted to put this in perspective when he noted the intensity of local politics in London, with 32 boroughs seeking the limelight, all of whom have to compete for publicity with the Mayor of London. This, the chief executive suggested, was significantly different from the situation in Middlesbrough or Bedford where the Directly Elected Mayor had little competition for the local media spotlight (Asquith, 2008). 
Hence, in terms of internal authority organisation, the key reforms here have been around the political management structure. The century-old traditional committee structure had been abandoned, and in its place local authorities were offered three options for change, all of which were designed to modernise the decision making process. Whilst the majority of local authorities chose the option of least change, the Leader with a Cabinet model, one of the sample authorities had opted for the more radical choice of the Mayor with a Cabinet model.

\section{External organisational dynamics}

The external environment within which local authorities now exist has been dramatically transformed since 1997 - all in the name of effectiveness and community engagement - observations made not only by all those interviewed for this article and further explored by Skelcher (2010b) . A raft of new initiatives have been launched (and dropped), designed to have a positive impact upon the operation of local government - all of which it could be argued fall within the remit of so-called 'Joined-UpGovernment' (JUG). Whilst many of these new enterprises have met with differing success levels, they have not been without their detractors. Indeed Painter et al (2003) noted wryly that local government has a bad case of 'initative-itis' caused by the stream of initiatives coming from various central government departments, with Stoker (2002) likening the situation to the national lottery. One chief executive commented:

I think that the drive to efficiency is over stretched, I think the degree of change and realignment and piloting things and then rolling them out before they have evaluated the pilot creates too much change and movement that can't be embedded and are destabilizing ultimately even if the ultimate goals are meant to be laudable.

One major note of warning was expressed by a chief executive who has direct experience of the machinery of both local and central government. He argued that an inherent danger of JUG was that rather than poorly performing services/organisations 'upping' their game to match the best performing partners, what could happen is an end result of mass mediocrity rather than public service excellence.

Whilst there have been attempts to provide co-ordination to these processes under the JUG agenda, there is still consternation that central government does not quite understand how and why local government operates. Indeed, one 2005 interviewee suggested that in terms of the public sector efficiency drive - the so-called Gershon Agenda - central government had much to learn from local authorities who after years of voluntary and involuntary competition ran very tight, efficient organisations (Gershon, 2004; Quirk, 2005). Gershon sought to identify efficiencies across the public sector and to redirect savings towards front-line services.

Further, it was suggested that for central government to pursue any form of JUG in relation to subnational government was a misnomer. Examples cited here related to the often conflicting agendas evident within local authority, police and health service organisations operating within one locality with each service being accountable to different central government departments and being funded 
separately. Indeed, one chief executive spoke of his frustration with such issues, and of how at a meeting with civil servants in London, he introduced two senior civil servants who had issued his authority contradictory directives - he told them to resolve the issue and let him know the outcome.

One aspect of the JUG agenda which had been taken to heart was the idea of networking to achieve policy goals. Given the holistic view of local governance which now dominates, it was argued that without networking and partnership working, it would be impossible for local agencies to deliver desirable outcomes. Reasons for adopting such modes of operation differed from authority to authority. Within S1, it was argued that given the dispersal of a small population within a large geographic area, to expect one agency to deliver all services was nonsense, and that partnership operations were an operational necessity not a government fad. Against this, it is important to note the observations of Painter et al (1997) that there was is a risk in partnership formation in that they can be time consuming, with the inherent danger that the wrong partnerships may be formed. Indeed, such an observation was made by one chief executive:

Partnership working is another example, who would deny it is a good thing, but we have partnerships coming out of our ears, and if we stop talking about how these partnerships link, how they work and who is on then, and the agendas and everything, sometimes I think would be more effective, so I think the new agenda is flawed, shall I say.

As such local authorities need a strategic view of their partnering activities, and of the associated transaction costs, described by Kumar and van Dissel thus:

Transaction costs are the costs of managing the interaction while keeping the opportunistic behaviour under control so that on-going co-operation between the units can be sustained (1996: 291)

What was most striking about the adoption and use of partnerships was how they crossed the political divide. By far the two greatest advocates amongst the sample were the two London boroughs. In the Conservative led authority the rationale for entering into partnerships was far removed from the politically motivated 'externalising' mentality which prevailed during the 1980s and early 1990s. Indeed, it was noted that services externalised during this period had in fact being brought back in house to facilitate more effective operations.

The good governance requirement placed on local government since the implementation of the Local Government Act (2000) had made partnership creation a necessity. Here, of specific note was the strategic partnership in the field of information and communication technologies, where expertise and investment outstripped the resources available in-house to the organisation. Elsewhere, in L1 a radical reforming flagship London borough, the local authority had aggressively pursued a policy of focussing on strategic service delivery and improvement. This had been achieved via a policy of partnership and externalising functions where it did not possess the necessary skills and resources in-house. Between 1991 and 2005 the authority transferred over 5,000 of its workforce into partner organisations. 
Hence, the partnership relationships were driven less by dogma and more by operational realities. Indeed another authority in the sample (S1) which in the early 1990s had been positively pursuing an agenda to externalise service delivery, was now seeking to use partnership arrangements in service areas as a means to regulate market mechanisms. This point is made by one chief executive thus:

When you came before (in 1991), the council was hell bent on outsourcing everything, I think it was outsourced too much, nearly all our care, now we are building our own care homes, and we are trying to regulate the market price, because we outsourced absolutely everything, and then you've got the private sector completely in control of the pricing mechanism for all care.

Here, local government is mirroring best practice from supply chain management, whereby organisations seek external partners to provide expertise in areas of activity and provide stability in operating environments (Christopher, 2005). Further, other benefits will also accrue for organisations seeking to develop a network stance vis a vis organisational positioning. The 'rules of the game' which govern the participation of any organisation within a network can act as a behaviour moderating tool. As such Jarillo, again drawing upon supply chain management experience, noted:

An emphasis on long term relationships is also essential to the development of trust, because it makes clear that the relationship itself is considered valuable. Therefore opportunistic behaviour, which could cause a severance of the relationship, will be considered less likely. $(1988, p .37)$

Alongside the formalised partnership arrangements identified above, there exists a raft of informal arrangements whereby local organisations with mutual areas of interest will seek to develop relationships with other bodies. Hence, the idea of the local government manager as a 'networker' or 'boundary spanner' (Williams, 2002) has emerged over recent years. Such relationships exist outside formal 'business' frameworks and relationships, and often depend for their existence and development on personality and mutual respect rather than power.

Hence, in examining the networking arenas within the two London boroughs, it was found that in L1, the Mayor who, has been a leading light in the activities of the authority for twenty years, is the consummate professional networker. In L2, however, the abilities of Leaders present different pictures. The Leader in the 1980s adopted a confrontational style, one not conducive to networking. This can be contrasted with the Leader in 2005 who was seen nationally as a leading player in local government, and locally as being instrumental in bringing strategic partners together on a number of issues, whilst providing the authority with an 'acceptable' national face.

Local government now has to conform to an impressive external inspection regime. The inspection environment can best be divided into two groupings: voluntary peer review and statutory review with the former being less formal than the latter. The lynchpin to the formal inspection regime was the Comprehensive Performance Assessment (CPA), published each year which ranks authorities according to a range of criteria, and awards a star rating accordingly - with four stars being the highest accolade. The rationale behind the CPA at the time of its introduction was that authorities judged to be 'excellent' would enjoy greater freedoms to innovate, raise and spend money and be inspected less. 
There was however some dissatisfaction that these freedoms had not materialised, and that alongside the retention of 'capping' powers, local government was still paying for the extreme actions of a small number of deviant councils. There was further dissatisfaction that the formal inspection regimes did not appear to be fully joined up. An example emerged from one authority of a seventeen-person inspection team to review a service area with a budget of $£ 400,000$, whilst the full blown CPA inspection team contained four members to examine corporate expenditure in excess of $£ 300 \mathrm{~m}$.

Within one of the sample authorities which had been hailed as a flagship authority during the Conservative era of Prime Ministers' Thatcher and Major, there was a feeling that the incoming Labour Government may have been harsher on it than on other local authorities, purely on political grounds. Indeed, it was suggested that with the election of New Labour in 1997, the authority had been 'cast into the political wilderness'. However, the CPA scores for the authority, which consistently rated it as 'excellent', allayed these fears.

There was nevertheless the feeling amongst the interviewees that the peer review processes provided an informal sounding board to ascertain 'where authorities are' and were useful 'mock' examinations prior to formal statutory reviews. Indeed one chief executive was seeking to ensure that all chief officers and elected members participated in at least one peer review each year. This, it was argued, would allow the authority to share its experience as an 'excellent' rated council with others, as well as seeking out best practice elsewhere to adopt and apply within their own organisation.

At the time of the 2005 interviews, one authority, L2 was preparing to have an Improvement and Development Agency peer review. The authority had successfully argued that the standard review mechanism was inappropriate for its circumstances. The authority had successfully argued that rather than been reviewed against other English authorities, its peers were in fact international local authorities, and that as such it should have a review panel which reflected this. Hence, in addition to the English peer reviewers, the inspection team contained a UK based local government chief executive with international local authority experience, and the mayor of a major US city.

Given the status and nature of the local authority, it was argued that only by having such a review could an accurate picture of where it stood alongside its peers be gained. Interestingly, whilst the 'standard' review ran from Monday to Friday, L2 insisted that its population swelled during the weekend, only by being under review over the weekend could the reviewers gain a feeling for the managerial tasks faced by the organisation. This emphasis on the importance of managing over the weekend is in stark contrast to the evidence which emerged from the interviews in the early 1990s when it was the accepted view that chief officers and senior elected members would often retire to the country for the weekend. 


\section{Conclusion}

From the interviews conducted in 2005, it was apparent was that local government was enjoying something of a renaissance. Local authorities were no longer explicitly seen as the collective whipping boy of central government held up as examples of public sector inefficiency. Whilst the evidence does not present a uniform picture of acceptance of the reforms post 1997, it was clear that local government can no longer be viewed as being 'under siege'. Rather, where reform was not uniformly welcomed, the resistance was far less hostile than that evidenced towards the local governance agenda of the Thatcher/Major years.

The opportunities afforded by central government have been seized by local authorities. Whereas the picture offered by Asquith in 1997 of a range of differing positions vis a vis local authority organisational development, the 2005 evidence points towards a less diverse picture. The emphasis on internal managerial and political efficiency and probity, combined with the need to pursue a wider strategic governance role, have combined to push all six authorities revisited towards the 'Entrepreneurial Citizenship' model. This has resulted in authorities pursuing the legislated agenda alongside a number of innovations which are specific to their locality - such as local partnership arrangements or democratic modernisation.

Whereas in the early 1990s innovation could be said to have been the domain of the two London boroughs, all six of those interviewed in 2005 indicated that their respective authorities shared a desire to drive the change agenda forward to both strengthen local services and the position of local democracy. What did remain constant, was the desire of the two London boroughs to continually set the pace and direction of change for local government as a whole. Given the success of a number of innovations to enhance the democratic process in L1, it will be interesting to see if central government seeks to replicate these successes elsewhere in England in the Localism agenda being pursued by the Conservative/Liberal coalition elected in 2010. Certainly early evidence regarding the increased uptake of the Directly Elected Mayor in the major urban areas has been far from a resounding success.

\section{References}

Asquith, A. (1997) Effecting change management in English local government, Local Government Studies, 23(4) 86-99.

Asquith, A. (1998) Non-elite employees perceptions of organisational change in English local government, International Journal of Public Sector Management. 11(4) 262-280.

Asquith, A. (2008) A Bullock, a Monkey and Robocop: An Assessment of the Directly Elected Mayor in English Local Government', Policy and Politics, 36( 1) 39-53.

Christopher, M. (2005) Logistics and supply chain management: Creating value adding networks. $3^{\text {rd }}$ ed Harlow: Pearson Education Ltd.

Dahler-Larsen, P. (Ed.) (2002) Social Bonds to City Hall. Odense: Odense University Press.

Davis, H. (1988) Local government under siege, Public Administration, 66( 1) 91-101. 
DETR (1998) Modern Local Government In Touch with the People. DETR (Department of Environment, Transport and the Regions): London

Gershon, P. (2004) Releasing Resources to the Frontline. London: HMSO.

Hartley, J.; Butler, M. J. R. and Benington, J. (2002) Local government modernisation: United Kingdom and comparative analysis from an organisational perspective, Public Management Review, 4(3) 387-404.

Jarillo, J. C. (1988) On strategic networks, Strategic Management Journal, 9(1) 31-41.

Kumar, K. and van Dissel, H. G. (1996) Sustainable collaboration: Managing conflict and cooperation in interorganisational systems, MIS Quarterly, 20(3) 279-300.

Le Grand, J. (2002) Motivation, agency and public policy. Of knights \& knaves, pawns \& queens. Oxford: OUP.

Mouritzen, P. E. and Svara, J. H. (2002) Leadership at the apex. Pittsburgh, Pa.: University of Pittsburgh Press.

Morphett, J. (1990). Power structures in local authorities - the role of the chief executive in local government policy making, Local Government Policy Making, 17(1) 49-55.

Morphett, J. (1993) The role of Chief Executives in local government. Harlow: Longman.

Morris, R. and Paine, R. (1995) Will you manage? The needs of local authority chief executives. Hemel Hempstead: ICSA Publishing.

Newman, J,; Raine, J. and Skelcher, C. (2001) Transforming local government: Innovation and modernisation, Public Money and Management, 21( 2) 61-68.

Norton, A. (1991) The role of the Chief Executive in English local government. Birmingham: University of Birmingham Institute of Local Government Studies.

Painter, C.; Isaac-Henry, K. and McAnulla, S. (2003) Modernising local government: Micro-organisational reform and changing local structural configurations, Local Government Studies, 29(4) 31-53.

Painter, C.; Isaac-Henry, K. and Rouse, J. (1997) Local authorities and Non-Elected Agencies: Strategic response and organisational networks, Public Administration, 75( 2) 225-245.

Quirk, B (2005) Localising efficiency - more than just saving money, Local Government Studies, 31(5) 615-625.

Quirk, B. (2006) Innovation in local democracy: The London Borough of Lewisham, Local Government Studies, 32(3) 357-372.

Rao, N. (200). Options for change: Mayors, cabinets or the status quo?, Local Government Studies, 29(1) 1-16.

Skelcher, C. (2010a) Managing in a Political World: The Life Cycle of Local Authority Chief Executives. Basingstoke: Palgrave.

Skelcher, C. (2010b) The Labour Government's local government agenda 1997-2009: The impact on memberofficer relationships, Local Government Studies, 36(3) 323-339.

Stoker, G. (2002) Life is a lottery: New Labour's strategy for the reform of devolved governance, Public Administration, 80(3) 417-434.

Thynne, I. (2003) Making sense of public management reform, Public Management Review, 5(3) 449-459.

Williams, P. (2002) The competent boundary spanner, Public Administration, 80(1) 103-124.

Wilson, D. (2005) The United Kingdom: An increasingly differentiated polity. In Denters, B. and Rose, L. E. (Eds.) Comparing local governance. Basingstoke: Palgrave.

Wilson, J. and Doig, A. (2000) Local government management: A model for the future?, Public Management, 2(1)57-83. 